\title{
Interactive effects of defoliation and water deficit on growth, water status, and mortality of black spruce (Picea mariana (Mill.) B.S.P.)
}

\author{
Hibat Allah Bouzidi ${ }^{1} \cdot$ Lorena Balducci $^{1} \cdot$ John Mackay $^{2,3,4} \cdot$ Annie Deslauriers $^{1}$ (D)
}

Received: 3 October 2018 / Accepted: 7 February 2019 / Published online: 22 February 2019

(C) INRA and Springer-Verlag France SAS, part of Springer Nature 2019

\begin{abstract}
- Key message Defoliation followed by water deficit showed time-dependent effects on plant water status and growth in black spruce (Picea mariana (Mill.) B.S.P.). Biotic stress negatively (during active defoliation by growing instars) and positively (after defoliation) affected plant water relations. However, water deficit, alone or combined with defoliation, prevails over defoliation-related stress for radial growth and sapling vitality.

- Context Tree vitality is influenced by multiple factors such as insect damage, water deficit, and the timing of these stresses. Under drought, positive feedback via the reduction of leaf area may improve the water status of defoliated trees. However, the effect on tree mortality remains largely unknown.

- Aims We investigated the effects of defoliation followed by a water deficit on tree growth, plant water status, and mortality in black spruce (Picea mariana (Mill.) B.S.P.) saplings.

- Methods In a controlled greenhouse setting, saplings were submitted to combined treatments of defoliation and water stress. To assess the impact of these stresses and their interaction, we measured phenology, twig development, secondary growth of the stem, water potential, and mortality of the saplings.

- Results Both defoliation and water deficits reduced growth; however, the effect was not additive. During active defoliation, we observed a higher evaporative demand and a lower midday leaf water potential $\Psi_{\text {md }}$. We observed an opposite pattern of response post-stress. Drought alone increased sapling mortality immediately after the stress period, but after c.a. 20 days, mortality rates remained similar following combined drought and defoliation.

- Conclusion Our results highlight two key periods during which defoliation affects plant water relations either negatively (during active defoliation) or positively (after defoliation). Mortality in defoliated saplings was reduced immediately following drought because available internal water increased in the stem.
\end{abstract}

Keywords Black spruce saplings $\cdot$ Spruce budworm · Defoliation · Irrigation regimes · Bud phenology · Primary growth · Physiological parameters

Handling Editor: Cyrille B. K. Rathgeber

Contribution of the co-authors All authors have contributed directly to the content of this work (study design, interpretation of the data, writing, and critical revision). H. Bouzidi, A. Deslauriers, and L. Balducci participated in the data analysis. J. Mackay and A. Deslauriers participated in the funding of the study.

This article is part of the topical collection on Wood formation and tree adaptation to climate

Annie Deslauriers

annie_deslauriers@uqac.ca

1 Département des Sciences Fondamentales, Université du Québec à Chicoutimi, 555 boulevard de l'Université, Chicoutimi, Québec G7H 2B1, Canada
2 Centre d'Étude de la Foret, Département des Sciences du Bois et de la Foret, Université Laval, Québec, QC G1V 0A6, Canada

3 Institut de Biologie Intégrative et des Systèmes, Université Laval, Québec, QC G1V 0A6, Canada

4 Department of Plant Sciences, University of Oxford, Oxford OX1 3RB, UK 


\section{Introduction}

The assessment of tree vitality must consider the effect of multiple stress factors that vary in terms of their timing, frequency, intensity, and interactions (Mitchell et al. 2013). Developing an understanding of the effects of multiple stress responses (i.e., additive, synergistic, or antagonistic effects, see Bansal et al. (2013)) remains a major challenge, although it is crucial to understand the physiological mechanisms of interactive effects. Indeed, the boreal forest faces increasing challenges linked to both drought and defoliating insects, cooccurring events that increase tree mortality (De Grandpré et al. 2019). Outbreaks of the eastern spruce budworm (Choristoneura fumiferana Clemens) are currently one of the major natural disturbances in the boreal forest (Bergeron et al. 1995; Rossi and Morin 2011; Simard et al. 2012). These events cause marked reductions in tree growth and increased stand mortality (Bouchard et al. 2005; Zhang et al. 2014). Drought is another important stress with rates of tree mortality in Canada's boreal forest increasing by $1.9 \%$ year $^{-1}$ in the eastern part to $4.9 \%$ year $^{-1}$ in the western portion between 1963 and 2008 (Peng et al. 2011). A recent study on trembling aspen in a mixed boreal forest of western Canada indicated that drought had a greater impact on decreasing growth than defoliation (Chen et al. 2017b). Do these multiple stress factors (defoliation followed by a water deficit) make spruce more or less susceptible to water stress and increase/decrease mortality?

Several studies have reported that xylem growth can be reduced under conditions of drought or severe drought (Chen et al. 2017a; Fernández-de-Uña et al. 2017; Forner et al. 2018; Giovannelli et al. 2007; Gruber et al. 2010; Oberhuber et al. 2011; Rossi et al. 2009). However, contrasting responses have been observed for the effects of both drought and defoliation on growth. No significant changes in height and diameter growth were observed in defoliated Eucalyptus globulus Labill. (Eyles et al. 2009; Quentin et al. 2012). Jacquet et al. (2014) showed that the radial growth of young Mediterranean conifers was reduced by defoliation. However, the interaction of drought and defoliation did not limit radial growth in Pinus pinaster Aiton (Jacquet et al. 2014). Experimental research on young trees is necessary to elucidate the simultaneous impacts of drought and defoliation on growth.

The ecophysiological responses to defoliation at the canopy level versus the leaf level are complex. Soil-to-leaf hydraulic conductance and leaf area play key roles in regulating water transport and gas exchange (Mencuccini 2003; Tyree 2003). Defoliation can improve tree water relations at the canopy level (Páez et al. 1995; Quentin et al. 2012), because the reduction in leaf area changes the water balance, increasing transpiration rates and the leaf-specific hydraulic conductance (Quentin et al. 2011). Similarly, whole-plant water relations show a less negative midday leaf water potential (Quentin et al. 2011; Salleo et al. 2003). In contrast, after 2-3 years of spruce budworm outbreaks, the relative water content of twigs can be reduced by an average of $8 \%$ in heavily defoliated mature balsam fir (Abies balsamea (L.) Mill.) (Deslauriers et al. 2015), indicating that the water status at the wholeplant level is reduced.

Under conditions of decreased soil water availability, a reduced stomatal conductance postpones or avoids dehydration during periods of water deficit (Bréda et al. 2006; Choat et al. 2018; Cochard et al. 2002). This efficient stomatal control prevents water loss and decreases of leaf water potential at a critical threshold for xylem dysfunction (Bond and Kavanagh 1999; Delzon and Cochard 2014; Tyree and Zimmermann 2002). Moreover, stomatal control occurs in black spruce at low leaf water potentials as high as 1.0 MPa to - 1.5 (Bernier 1993; Stewart et al. 1995). More negative water potential has been linked to tree mortality after drought due to loss of hydraulic conductivity with a xylem air entry pressure (P12) of $-2.9 \mathrm{MPa}$ (Balducci et al. 2015). Xylem vulnerability to water stress is associated with leaf water potential where $50 \%$ of xylem tracheids are not working (Brodribb and Cochard 2009). Thus, the risk of hydraulic failure could be heightened under defoliation, as trees can maintain a high level of gas exchange, even during drought periods, to increase carbon gain at the cost of reducing water potential and thus loss of hydraulic conductivity (Salmon et al. 2015). Nevertheless, studies of plant water status can add significant knowledge regarding transpiration dynamics and tree vitality under conditions of both defoliation and drought.

Here, we investigate the effects of defoliation by the eastern spruce budworm followed by a water deficit on growth, plant water status, and mortality of black spruce saplings within a controlled greenhouse experiment. We expected the following responses:

(1) Plant water status is expected to decrease (negative effect) following a water deficit. Under defoliation, plant water status is expected to improve (positive effect) because of reduced transpiration in the defoliated saplings. The combined effect of a water deficit and defoliation should therefore be less negative than that of a water deficit alone because of an additive effect (the sum of the negative and positive effects of both water deficit and defoliation, respectively);

(2) Both defoliation and water deficit will cause growth reductions, and their combined effects will be additive (the sum of) or synergistic (greater than the sum of the separate effects of defoliation and water deficit);

(3) Mortality rates are expected to follow a pattern similar to that of water status (Hypothesis 1), with higher mortality rates under conditions of water deficit and lower rates under the combined effect of a water deficit and defoliation. 


\section{Materials and methods}

\subsection{Experimental design}

The experiment ran from May to September 2014 in a greenhouse at the Université du Québec à Chicoutimi (QC, Canada, $\left.48^{\circ} 25^{\prime} \mathrm{N}, 71^{\circ} 04^{\prime} \mathrm{W}\right)$. The plants were 6-year-old black spruce saplings placed in plastic pots $(11.4 \mathrm{~L})$ filled with perlite and peat moss vermiculite. The plants' mean stem base diameter was $18.0 \pm 3.2 \mathrm{~mm}$, and the mean height was $73.5 \pm$ $13.1 \mathrm{~cm}$. Each sapling received a single dose of $1 \mathrm{~L}$ of $20-20$ 20 fertilizer at $6 \mathrm{~g} \mathrm{~L}^{-1}$ at the beginning of the experiment. The saplings were grown under natural daylight and local photoperiod conditions. The average temperature was $20.2{ }^{\circ} \mathrm{C}$ throughout the experiment. The average maximum temperature was $26.3{ }^{\circ} \mathrm{C}$, while the average minimum temperature was $13.9^{\circ} \mathrm{C}$.

The experimental design consisted of 192 saplings in four fully replicated blocks (compartments), each with of 48 plants, divided into four treatments according to a split-split-plot design. Each block was split into two defoliation treatments (24 plants for each treatment), one with spruce budworm (named defoliated) and one without spruce budworm (named undefoliated). All treatment plots were surrounded by border plants. The 24 plants in each defoliation treatment were further subdivided into two irrigation treatments, i.e., irrigated (I) and non-irrigated (NI), and were set out as 12 plots having two plants each. Enclosures were placed over the plants to avoid the migration of larvae; they were made of a wooden frame $(288 \mathrm{~cm}$ high $\times 183 \mathrm{~cm}$ wide $\times 173 \mathrm{~cm}$ high $)$ covered with a fine textile net (proteknet $60 \mathrm{~g}$; mesh size of $1.9 \times$ $0.95 \mathrm{~mm}$ ) that allowed the passage of $93 \%$ of light. For the spruce budworm defoliation treatment, 125 larvae at the L2 stage (standard code Glfc:IPQL:Cfum01 to Cfum16, Roe et al. (2018)) were applied in groups of 25 onto the first whorls of each sapling when more than $50 \%$ of the apical buds had reached a stage 3 (see description of bud phenology). Each pot was irrigated via drip watering. All plants received $1.2 \mathrm{~L}$ of water per day during the initial part of the experiment up to the day of the year (DOY) 160. For the NI treatment, irrigation ceased for 23 days (from DOY 160 to DOY 182) during the phase of active primary growth (Zhai et al. 2012). When the pre-dawn water potential $\left(\Psi_{\mathrm{pd}}\right)$ dropped under $-3 \mathrm{MPa}$ in NI plants, irrigation was resumed from DOY 183 until the end of the experiment.

\subsubsection{Bud phenology and growth}

We measured phenology and growth twice per week for 48 randomly selected trees ( 12 trees $\times 2$ defoliation treatments $\times$ 2 irrigation regimes). The observation of bud stages followed Dhont et al. (2010) and Rossi and Isabel (2017) and corresponded to the following: 1 , open bud; 2 , elongated bud; 3 , swollen bud; 4, translucent bud; 5 , split bud; 6 , exposed shoot. Two branches of the first whorl were selected for lateral growth measurements, and an electronic caliper (mm) was used to record this growth. The stem radius $(\mathrm{mm})$ of 18 saplings was measured using automatic point dendrometers (LVDT, Macro Sensor PR750, Pennsauken, NJ). Dendrometers were appositely constructed to fit on small stems with a sensing rod held by a constant force against the outer surface of the bark and at about $5 \mathrm{~cm}$ above the collar. The stem size was recorded every $15 \mathrm{~min}$ and was averaged over each day (Deslauriers et al. 2007).

\subsubsection{Spruce budworm}

Spruce budworm development stages (phenological instar stages L2 to L6 and pupae stage 7) were determined based on the size of the head capsule of the larvae according to the insect's life history (Deslauriers et al. 2019; Pureswaran et al. 2015). Instar phenology was monitored on three larvae twice per week, randomly picked from 48 randomly selected trees (12 trees $\times 2$ defoliation treatments $\times 2$ irrigation regimes) and then put back onto the sapling. An overall plant defoliation level was determined visually on saplings branches, according to the shoot-count method (Maclean and Lidstone 1982; Piene et al. 1981). We used six defoliation classes that correspond to a median percentage of defoliation (Deslauriers et al. 2019).

\subsubsection{Plant water status}

The measurements of plant water status involved destructive samplings and used 16 different saplings ( 4 trees $\times 2$ defoliation treatments $\times 2$ irrigation regimes). The pre-dawn leaf water potential $\left(\psi_{\mathrm{pd}}\right)$ and midday leaf water potential $\left(\psi_{\mathrm{md}}\right)$ were measured using a pressure chamber (PMS Instruments, Corvalis, OR, USA). We took $\psi_{\text {pd }}$ measurements between 2:00 AM and 4:00 AM and $\psi_{\mathrm{md}}$ measurements between 9:00 AM and 11:00 AM. The relative soil water content (VWC) was monitored using a TDR probe (time domain reflectometer, Fieldscout 300). The measurements were taken at 7-cm depth in each pot and replicated twice (Topp et al. 1984).

\subsubsection{Plant mortality}

Sapling mortality was determined by considering the main damaged structural components: complete needle wilting, cambium collar, and stem necrosis (Balducci et al. 2013). Every week, following the stress period, we calculated the mortality rate (percentage, \%) from the total number of saplings that had died within each of the defoliation and irrigation treatments. 


\subsection{Statistical analysis}

Bud and larvae phenology were analyzed as qualitative variables. The average date $(\bar{x})$ and standard deviation $\left(s_{\bar{x}}\right)$ at which the $E_{i}$ stage (from 1 to 6 ) occurred were determined according to:

$$
\begin{gathered}
\bar{x}=\frac{\sum_{i=1}^{k} f_{E_{i}} \times x_{i}}{n} \\
S_{\bar{x}}=\sqrt{\frac{\sum_{i=1}^{k}\left(x_{i}-\bar{x}\right)^{2}}{n-1}}
\end{gathered}
$$

where $x_{i}$ is the date expressed in DOY, $f_{E_{i}}$ is the frequency of the $E_{i}$ stage, and $k$ is the number of sampling dates [adapted from Scherrer 2007]. To compare the progression of the phenological stages between treatments, we developed ordinal regression models using the LOGISTIC procedure in SAS (SAS Institute, Cary, NC, USA). Differences between defoliation treatments and irrigation regimes were identified using the LSMEANS option with a Bonferroni multiple test comparison.

A Gompertz function (NonLINear regression, SAS) was fitted to apical and lateral growth to determine the total growth achieved and growth rate (Deslauriers et al. 2003). The Gompertz function was defined as:

$y=I+A \exp \left[-e^{\beta-K t}\right]$

where $y$ is weekly cumulative growth $(\mathrm{mm}), t$ the time computed in DOY, $I$ is the initial growth value $(\mathrm{mm})$ at bud burst, $A$ the upper asymptote $\beta$ the $x$-axis placement parameter, and $\kappa$ the rate of change of the shape (Rossi et al. 2003). A weighted mean absolute cell formation rate $\left(r\right.$, cell·day $\left.{ }^{-1}\right)$ was also calculated (Deslauriers et al. 2003):

$r=\frac{A \kappa}{4}$

Repeated mixed-effect models (MIXED procedure in SAS) evaluated the effects of defoliation treatment and irrigation regimes on defoliation (\%), apical and lateral growth $(\mathrm{mm})$, soil relative water content $(\%)$, and water potential $\left(\Psi_{\mathrm{pd}}\right.$ and $\left.\Psi_{\mathrm{md}}, \mathrm{MPa}\right)$. Defoliation and irrigation treatments were the fixed factors while compartment and tree (nested in compartment $\times$ defoliation treatment irrigation regime) were the random factors. The DOY effect was considered as the repetitive factor with tree as subject (nested in compartment $\times$ defoliation treatment $\times$ irrigation regime). We ran the VCIRY option (MIXED procedure in SAS) to test the distribution of the data, and we plotted the model residuals to verify their distribution.

\section{Results}

\subsection{Phenology, defoliation, and growth}

The phases of budburst proceeded similarly among the different treatments (Fig. 1, Table 1). The bud development phases varied significantly between the different dates (Wald $=513$, $P<0.001$, Table 1) showing a linear trend. No differences were found between the defoliation treatments and irrigation regimes, although their interaction was significant $(P=0.001$, Table 1). For all treatments, buds began their development on DOY 135 and ended 4 weeks later on DOY 162-163 (Fig. 1). The transition from one stage to another took 4.66 days on average.

Spruce budworm development took approximately 25 days (4.16 days per stage) with a linear trend over time. Development was not affected by the irrigation regime, as instar development was almost complete when the treatments began (Table 1). The L5-L6 instars were able to feed on split buds (bud stage 5, exposed shoots) after DOY 160 . Thus, defoliation began when the new shoots and needles started to grow, and defoliation stopped increasing when pupas were observed (Fig. 1). Afterward, defoliation varied according to the different sampled trees. Defoliation was already high at DOY 164, and it did not differ between the irrigated (37.5\%) and non-irrigated saplings (39.2\%) (Table 2).

Apical and lateral shoot growth had already stopped in the defoliated plants by the fifth instar stage, around the time that defoliation began (Fig. 2). From that moment onward, primary growth slowed significantly in the defoliated plants compared to the undefoliated plants (Table 3). Apical and lateral growth were affected more strongly by the defoliation treatments than by the irrigation treatments as half of the total primary growth had occurred when irrigation ceased (Tables 2 and 3, Fig. 2).

In the defoliated-irrigated saplings, radial growth slowed as a result of defoliation (Fig. 3), and this reduction was significant by the end of September $(P<0.001)$. The largest differences in the patterns of stem radial variation were observed between the irrigated and non-irrigated saplings $(P<0.001)$ with a mean radial growth $0.6 \mathrm{~mm}$ less in the latter. The radial growth stopped soon after the irrigation ceased (DOY 160). Minimal increase in stem radius was detected in the defoliated saplings following the water deficit period (Fig. 3). A typical downward wave was observed in the undefoliated-non-irrigated saplings with minimal growth afterward, indicative of elevated stem shrinking. However, this stem shrinking was not observed in the defoliated-non-irrigated saplings. At the end of September (DOY 273), both undefoliated-non-irrigated and defoliated-non-irrigated saplings had similar radial growths $(P=0.58)$. 
Fig. 1 Black spruce bud and spruce budworm larvae development and defoliation. a, b The phases of bud development in irrigated and non-irrigated black spruce saplings with (black triangles) or without (circles) defoliation. The horizontal bars represent the standard deviation of the mean phenological date. c, d Level of defoliation for irrigated and non-irrigated defoliated saplings. The vertical bars represent the standard deviation. The shaded gray areas indicate the stress periods, either defoliation alone (a and $\mathbf{c}$ ) or combined defoliation and water stress (b and d)

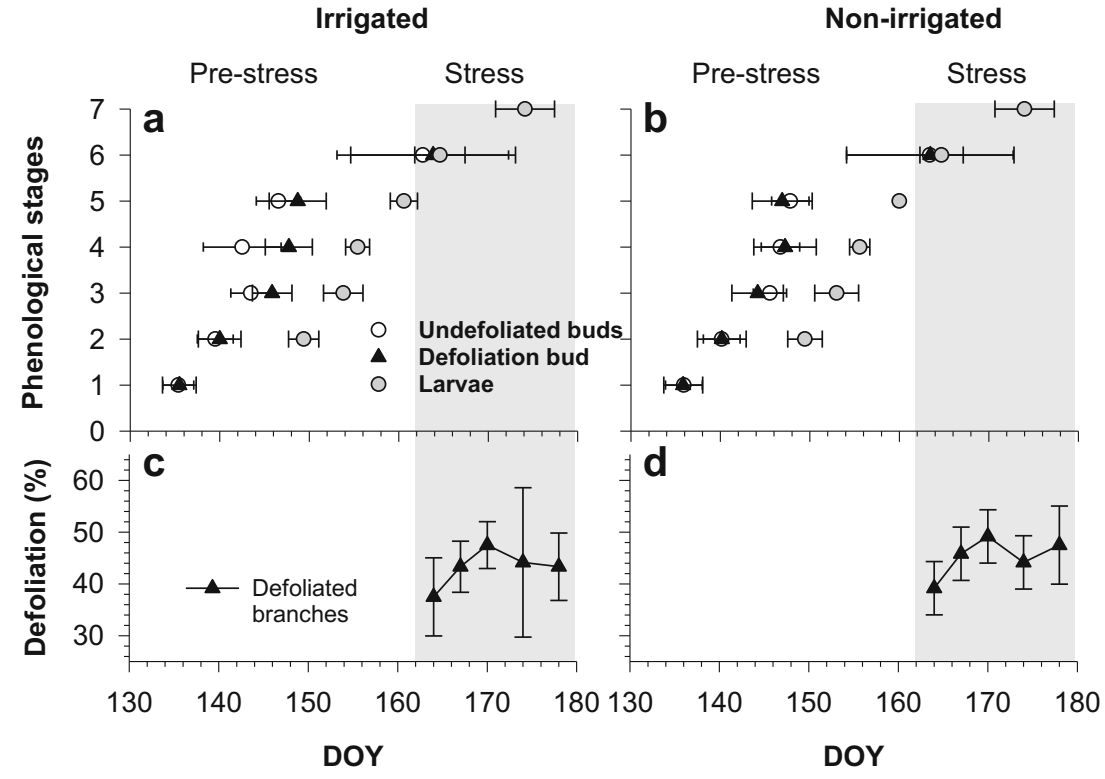

\subsection{Soil water status and water relations}

We examined soil moisture and water relations by delineating three different periods based on the treatment effects: (1) the pre-stress period (DOY < 162), i.e., no visible defoliation (instar stage 4 at most) and no water deficit; (2) the stress period (DOY 163-184) beginning with the peak in defoliation and growth damage (instar stages 5 and 6 ) and ending at the peak of water deficit - this period also covered the lowest levels of the volumetric water content; (3) the post-stress period beginning when irrigation was resumed (DOY $>182)$.

In the pre-stress period, the mean soil moisture varied from 32 to $42 \%$ and showed no difference between the irrigation treatments (Table 4, Fig. 4). The plants reflected optimal water conditions, with pre-dawn $\left(\Psi_{\mathrm{pd}}\right)$ water potential ranging between -0.2 and $-1.0 \mathrm{MPa}$ and midday $\left(\Psi_{\mathrm{md}}\right)$ water potential ranging between -0.1 and $-1.4 \mathrm{MPa}$ in both the irrigated and

Table 1 Results of the ordinal logistic regressions including the effect of day of the year (DOY), defoliated treatments $(D$, undefoliated and defoliated), and irrigation regimes ( $I$, irrigated and non-irrigated) on the bud-break stage and spruce-budworm instars (larvae)

\begin{tabular}{llrll}
\hline Phenology & Effect & Wald $\kappa^{2}$ & $\nu$ & $P$ \\
\hline Bud & DOY & 533.73 & 1 & $<0.001$ \\
& D & 2.42 & 1 & NS \\
& I & 3.17 & 1 & NS \\
& D $\times$ I & 10.92 & 1 & 0.001 \\
Larvae & DOY & 106.23 & 1 & $<0.001$ \\
& I & 40.56 & 2 & NS \\
\hline
\end{tabular}

The results include the Wald $\kappa^{2}$ statistic, degree of freedom $(\nu)$, and probability $(P)$ for each effect. The probability $(P)$ is reported as not significant (NS) when $P>0.05$ non-irrigated saplings having similar defoliation and irrigation treatments.

Table 2 Repeated mixed models for defoliation (\%) and apical and lateral growth $(\mathrm{mm})$ for the defoliated treatments $(D$, undefoliated and defoliated) and irrigation regimes ( $I$, irrigated and non-irrigated)

\begin{tabular}{|c|c|c|c|c|}
\hline Growth & Effect & $\nu_{1}, \nu_{2}$ & $F$ & $P>F$ \\
\hline \multirow[t]{7}{*}{ Defoliation } & $\mathrm{D}$ & 1,41 & 3174 & $<0.001$ \\
\hline & I & 1,41 & 1.63 & NS \\
\hline & $\mathrm{D} \times \mathrm{I}$ & 1,41 & 1.63 & NS \\
\hline & DOY & 4,176 & 7.10 & $<0.001$ \\
\hline & $\mathrm{DOY} \times \mathrm{D}$ & 4,176 & 7.10 & $<0.001$ \\
\hline & $\mathrm{DOY} \times \mathrm{I}$ & 4,176 & 0.31 & NS \\
\hline & $\mathrm{DOY} \times \mathrm{D} \times \mathrm{I}$ & 4,176 & 0.31 & NS \\
\hline \multirow[t]{7}{*}{ Apical } & $\mathrm{D}$ & 1,43 & 15.75 & $<0.001$ \\
\hline & I & 1,43 & 0.51 & NS \\
\hline & $\mathrm{D} \times \mathrm{I}$ & 1,43 & 17.26 & $<0.001$ \\
\hline & DOY & 9,344 & 32.04 & $<0.001$ \\
\hline & $\mathrm{DOY} \times \mathrm{D}$ & 9,344 & 1.41 & NS \\
\hline & $\mathrm{DOY} \times \mathrm{I}$ & 9,344 & 0.03 & NS \\
\hline & $\mathrm{DOY} \times \mathrm{D} \times \mathrm{I}$ & 9,344 & 0.56 & NS \\
\hline \multirow[t]{7}{*}{ Lateral } & $\mathrm{D}$ & 1,43 & 63.87 & $<0.01$ \\
\hline & I & 1,43 & 0.63 & NS \\
\hline & $\mathrm{D} \times \mathrm{I}$ & 1,43 & 5.68 & $<0.05$ \\
\hline & DOY & 9,344 & 43.29 & $<0.001$ \\
\hline & $\mathrm{DOY} \times \mathrm{D}$ & 9,344 & 6.02 & $<0.001$ \\
\hline & $\mathrm{DOY} \times \mathrm{I}$ & 9,344 & 0.13 & NS \\
\hline & $\mathrm{DOY} \times \mathrm{D} \times \mathrm{I}$ & 9,344 & 0.09 & NS \\
\hline
\end{tabular}

The effect of day of the year (DOY) was considered as the repeated variable. The results include for each effect degree of freedom $\left(\nu_{1}, \nu_{2}\right)$, $F$ statistic and probability $(P)$. The probability $(P)$ is reported as not significant (NS) when $P>0.05$ 
Fig. 2 Apical and lateral growth $(\mathrm{mm})$ in control (circles) and defoliated (black triangles) saplings for the irrigated and nonirrigated (gray box) regimes. The vertical bars represent the standard deviation. Different letters indicate significant effects between the defoliation treatments and irrigation regimes according to the repeated mixed models $(P<0.05)$. The shaded gray areas indicate the stress periods, either defoliation alone (a and c) or combined defoliation and water stress (b and $\mathbf{d}$ )
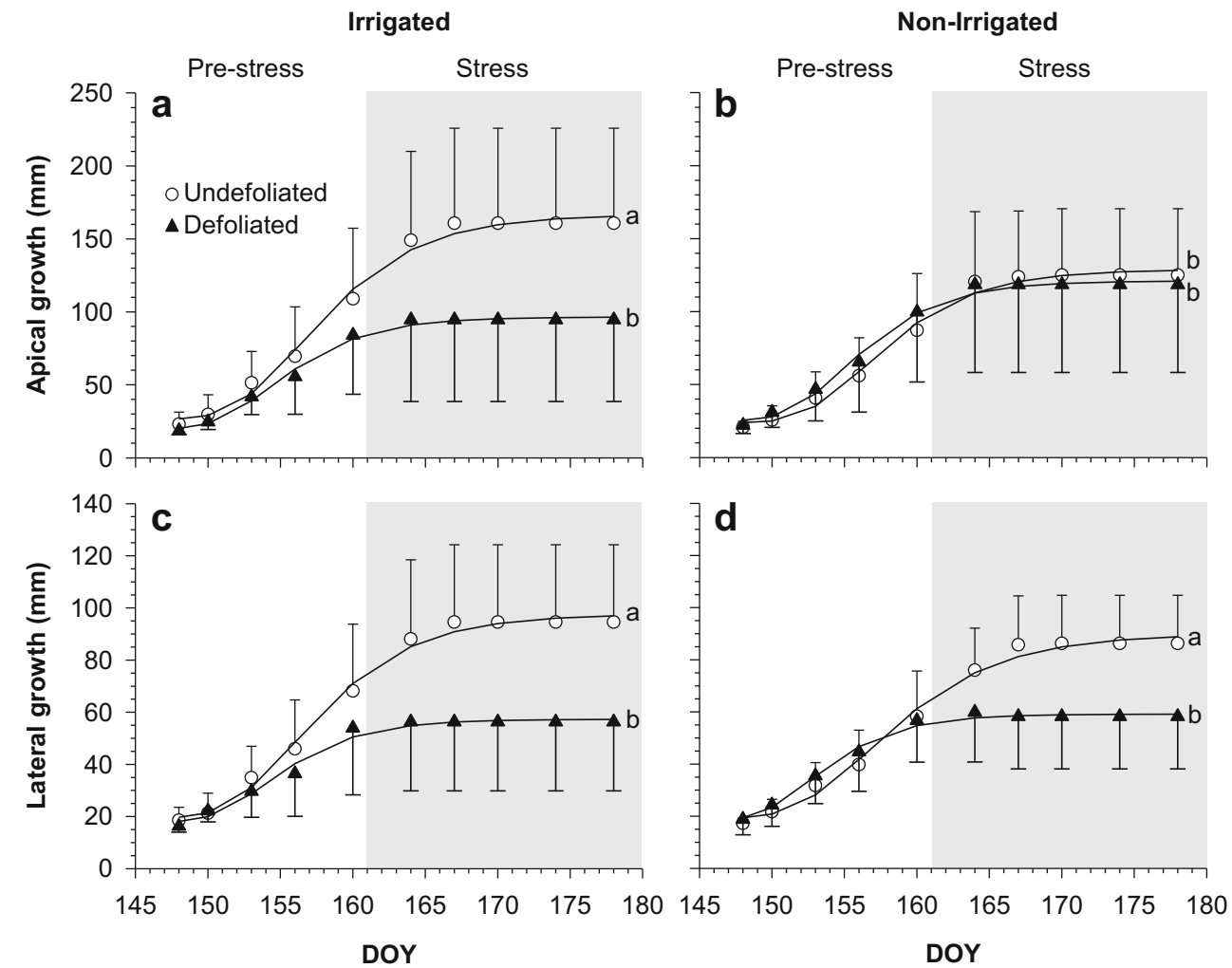

During the stress period, soil moisture decreased markedly in the non-irrigated pots after DOY 162. Minimum soil moisture was recorded in DOY $175-184$ with levels $<10 \%$ to c.a. zero in the non-irrigated pots. Similarly, both $\Psi_{\mathrm{pd}}$ and $\Psi_{\mathrm{md}}$ were significantly lower in the non-irrigated saplings relative to the irrigated saplings $(P<0.01$, Table 4 , Fig. 4). The water potential of non-irrigated plants reached $\Psi_{\mathrm{pd}}$ and $\Psi_{\mathrm{md}}$ levels of -2.5 and $-2.7 \mathrm{MPa}$, respectively. The midday water potential ( $\left.\Psi_{\mathrm{md}}\right)$ was not significantly affected by the defoliation treatment, but a significant interaction was found for defoliation $\times$ irrigation $(P<0.05$, Table 4$)$. Differences of least squares means (LSM) revealed that the midday water potential of undefoliated-irrigated saplings (LSM $\left.\Psi_{\mathrm{md}}=-1.20 \mathrm{MPa}\right)$ was significantly less negative than all other treatment combinations, including the defoliated-irrigated saplings (LSM $\left.\Psi_{\mathrm{md}}=-1.51 \mathrm{MPa}\right)$. The non-irrigated saplings had similar $\Psi_{\text {md }}(-1.71$ and $-1.56 \mathrm{MPa}$ for the undefoliated and defoliated treatments, respectively), which did not differ from the defoliated-irrigated saplings.

In the post-stress period, the soil moisture increased rapidly but only returned to levels similar to that of the irrigated pots after DOY 191, producing a significant difference during the post-stress period ( $P<0.01$, Table 4$)$. After resuming irrigation, the pre-dawn water potential $\Psi_{\mathrm{pd}}$ increased and returned to levels similar to those observed prior to the stress period. However, after the stress period, the $\Psi_{\text {md }}$ of the defoliated saplings was less negative than that of the undefoliated saplings (Fig. 4).
Table 3 Apical and lateral growth fittings $(\mathrm{mm})$ for the defoliated treatments (control and defoliation) and the irrigation regimes (irrigated (I) and nonirrigated (NI))

\begin{tabular}{|c|c|c|c|c|c|c|c|c|}
\hline \multirow[t]{3}{*}{ Treatment Irrigation } & \multicolumn{4}{|c|}{ Apical growth } & \multicolumn{4}{|c|}{ Lateral growth } \\
\hline & \multicolumn{2}{|l|}{ Control } & \multicolumn{2}{|c|}{ Defoliation } & \multicolumn{2}{|l|}{ Control } & \multicolumn{2}{|c|}{ Defoliation } \\
\hline & $I$ & NI & $I$ & NI & $I$ & NI & $I$ & NI \\
\hline$I$ & 27.66 & 25.93 & 21.41 & 26.82 & 19.83 & 20.74 & 20.28 & 17.79 \\
\hline$A$ & 138.80 & 102.4 & 75.00 & 94.05 & 83.05 & 68.68 & 36.80 & 37.63 \\
\hline$\beta$ & 34.95 & 39.37 & 42.67 & 42.46 & 35.34 & 32.91 & 48.71 & 48.93 \\
\hline$\kappa$ & 0.2234 & 0.2514 & 0.2762 & 0.2738 & 0.2266 & 0.2097 & 0.3152 & 0.3205 \\
\hline$r$ & 7.75 & 6.43 & 5.18 & 6.43 & 4.70 & 3.60 & 2.89 & 3.01 \\
\hline
\end{tabular}

The fitted parameter, $I$, represents the initial growth $(\mathrm{mm}) ; A, \beta$, and $\kappa$ represent the parameters of the Gompertz function; and $r$ indicates a weighted mean absolute rate $\left(r, \mathrm{~mm} \mathrm{day}^{-1}\right)$ 
Fig. 3 Radius increases at the basis of the stem measured by automatic point dendrometers on control (black) and defoliated (gray) saplings. Different letters indicate significant effects between the defoliation treatments and irrigation regimes $(P<0.05)$. The shaded gray areas indicate the stress periods, either defoliation alone (a) or combined defoliation and water stress (b)

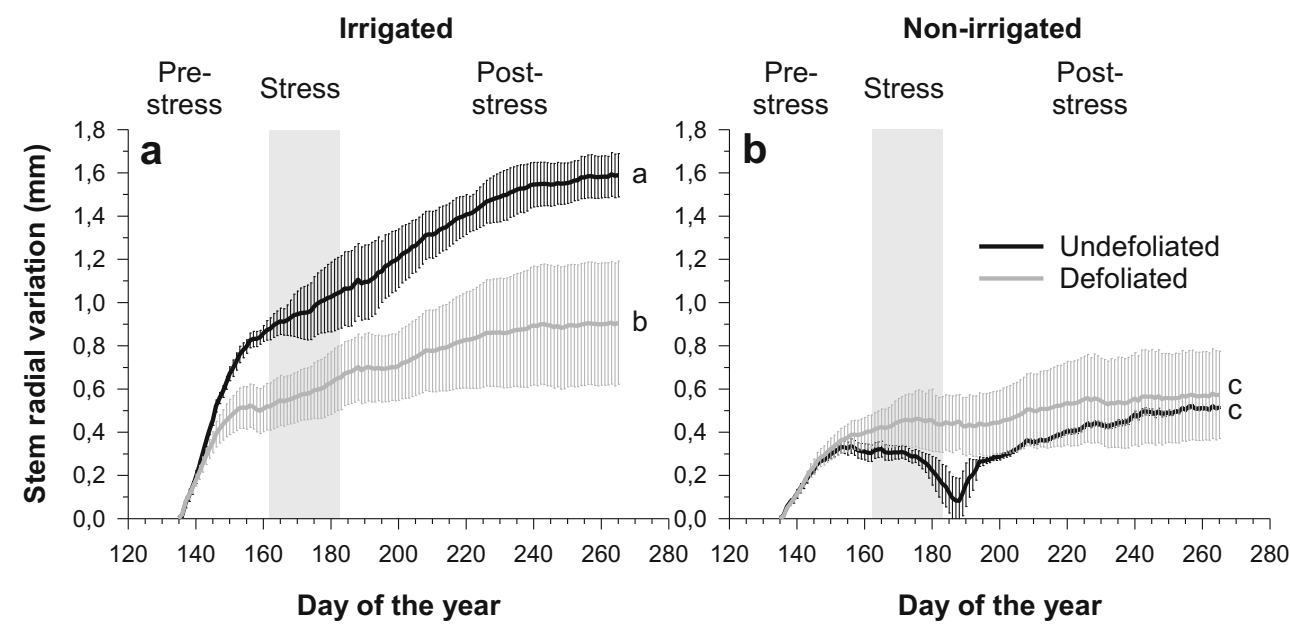

the stress period but differed between the undefoliated and defoliated plants; undefoliated-non-irrigated saplings had higher mortality rates during the first 2 weeks after resuming irrigation $\left(0.3\right.$ dead-sampling $\cdot$ day $\left.^{-1}\right)$ compared to defoliated-non-irrigated plants $\left(0\right.$ dead sampling day $\left.{ }^{-1}\right)$ (Fig. 5). After these 2 weeks, mortality rates were similar $\left(0.05-0.1\right.$ dead $\cdot$ sampling $\cdot$ day $\left.^{-1}\right)$.

\section{Discussion}

\subsection{Plant water status}

Leaf water status was more affected by the amount of irrigation than defoliation in black spruce saplings exposed to spruce budworm defoliation immediately followed by a water deficit. Most previous studies investigating combined stresses have had the abiotic stress followed by a biotic stress; these studies concluded that drought stress predisposes trees to pathogen attacks (see review in Niinemets (2010)). Here, we assessed the reverse effects-biotic and then abiotic stressors - because spruce budworm outbreaks are cyclical (Morin et al. 1993). Thus, we could test the effect of drought on plant water status, growth, and mortality in trees weakened by defoliation. In contrast to the prediction for defoliation (first hypothesis), all non-irrigated saplings (defoliated or not) reached a similar water status in the nighttime $\left(\Psi_{\mathrm{pd}}\right)$ and daytime $\left(\Psi_{\mathrm{md}}\right)$ during the stress period. Therefore, under situations of coupled defoliation and water stress, defoliation did not have a positive effect on water potential. In black spruce, significant decreases in soil water content and water potential have been reported under scenarios of water deficit (Balducci et al. 2013; Tan and Blake 1997), with leaf $\Psi_{\mathrm{pd}}$ fluctuating between -2.2 and - 2.9 MPa (Balducci et al. 2013; Stewart and Bernier 1995; Zine El Abidine et al. 1994). At the end of the stress period, all non-irrigated saplings had a limited ability to take up water from the soil as $\Psi_{\mathrm{pd}}$ dropped when the relative water content reached zero. This placed all the
The day of the year (DOY) effect was considered as the repeated variable for each period (pre-stress, stress, post-stress). Probability $(P)$ is reported as not significant (NS) when $P>0.05$ 
Fig. 4 Soil water status (volumetric water content (VWC, $\%)$, pre-dawn ( $\left.\Psi_{\text {pd }}, \mathrm{MPa}\right)$, and midday $\left(\Psi_{\mathrm{md}}, \mathrm{MPa}\right)$ water potential of black spruce saplings subjected to defoliation and water deficit treatments. Different letters indicate significant differences $(P<0.05)$ in the defoliated treatments. Similarly, asterisks $(*)$ indicate significant differences $\left({ }^{* *} P<0.01,{ }^{* * *} P<0.001\right)$ in the irrigation regime (see Table 4 for details). The shaded gray areas indicate the stress periods, either defoliation alone (on the left panel) or combined defoliation and water stress (on the right panel)
Irrigated
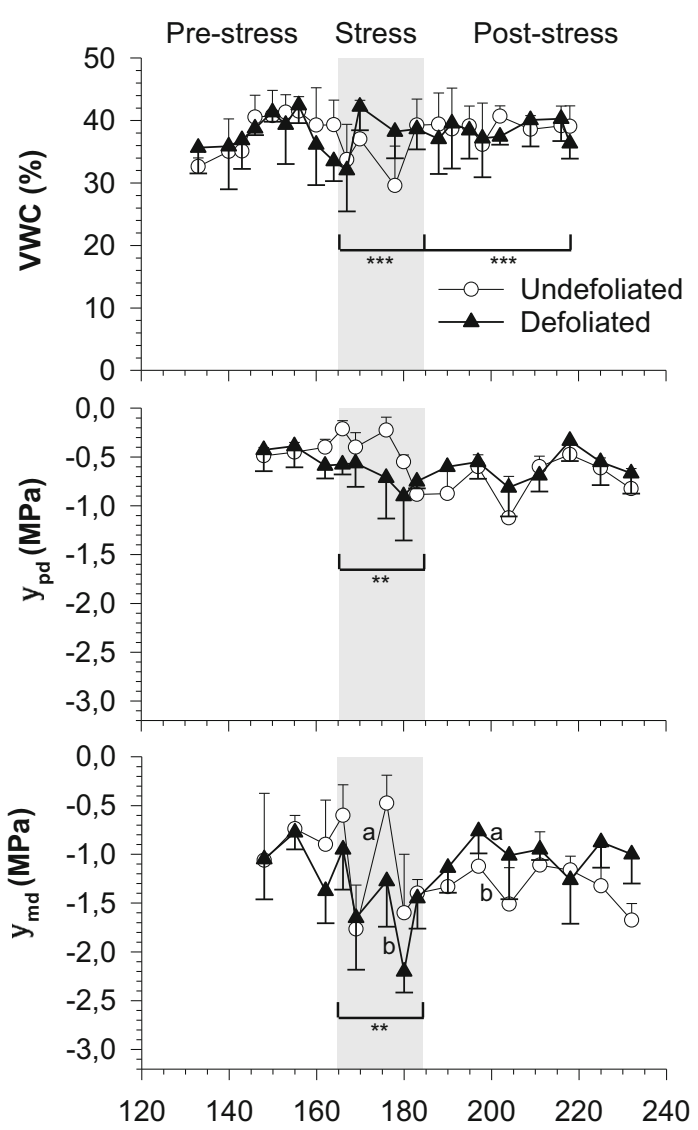

Non-Irrigated
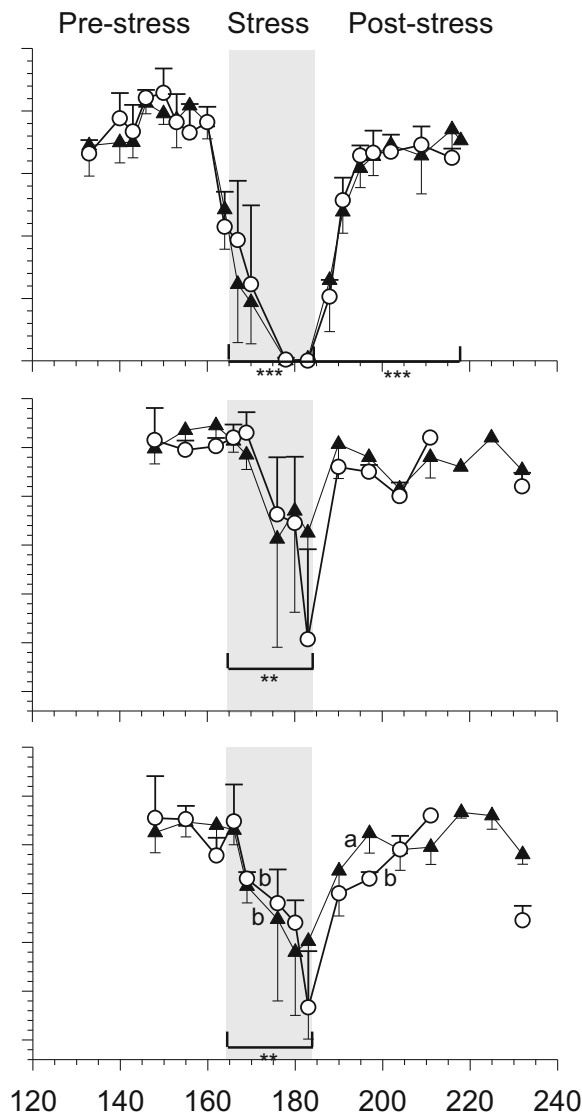

Day of the year

saplings in a physiological state of water stress (Bernier 1993; Grossnickle and Blake 1987; Stewart and Bernier 1995).
Contradictory responses were found in other studies where the leaf $\Psi_{\text {md }}$ of defoliated plants was either higher (Quentin et al. 2011; Vanderklein and Reich 2000; Wiley et al. 2013) or
Fig. 5 Mortality $r$ starting 1 week after the end of the stress period (shaded gray area) for nonirrigated black spruce saplings subjected to defoliation treatments (undefoliated and defoliated)

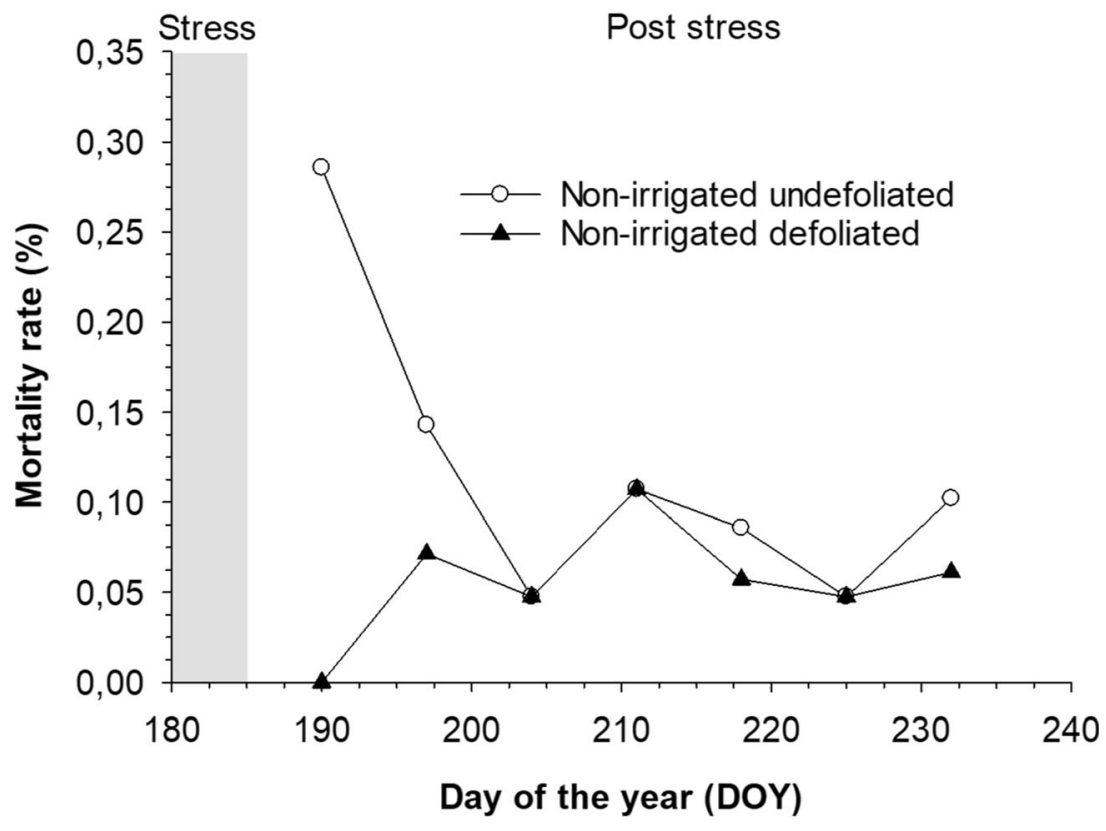


similar (Quentin et al. 2012) to undefoliated plants. This pattern can be related to the timing of measurements. In this study, we observed two different responses of $\Psi_{\mathrm{md}}$ : a detrimental effect during defoliation and the opposite pattern during the post-stress period, thus partially confirming our first hypothesis. In irrigated plants, $\Psi_{\mathrm{md}}$ was significantly lower in defoliated plants relative to the undefoliated plants. This indicates a higher evaporative demand during or immediately following defoliation (Salmon et al. 2015). Eyles et al. (2013) also report a decrease in $\Psi_{\mathrm{md}}$ for saplings subjected to different levels of defoliation ( $50 \%$ or $100 \%$ apical bud damage). We explained this lower $\Psi_{\mathrm{md}}$ by the mechanical chewing action of larvae during active defoliation (i.e., Fig. 1). Budworm feeding habits damage many growing needles, resulting in a loss of turgor or even localized cavitation because of the entry of air into the damaged needles. This likely decreases the water potential. The opposite pattern was observed during the post-stress period: leaf $\Psi_{\mathrm{md}}$ was less negative in the defoliated saplings than in the undefoliated saplings. These results are similar to patterns observed in Larix decidua Mill., Pinus strobus L., and Quercus velutina Lam. (Vanderklein and Reich 2000; Wiley et al. 2013). In the post-stress period, direct defoliation ceased, but the reduced leaf area of defoliated saplings led to a lower leaf transpiration surface (Schmid et al. 2017; Wiley et al. 2013). From DOY $190-230$, a greater gradient of leaf $\Psi_{\text {md }}$ was observed in undefoliated saplings due to persistently higher growth temperatures. These lower $\Psi_{\mathrm{md}}$ values could indicate higher transpiration occurred during the day and reduced the optimal water status.

\subsection{Plant growth}

Apical shoot and twig growth were reduced primarily by defoliation but without additive or synergistic effects from the combined stresses (second hypothesis). Although black spruce is considered as a secondary host (Hennigar et al. 2008; Pureswaran et al. 2015), the L2 instars deposited on the branch rapidly colonized the plants and began growing quickly, defoliating the growing buds and shoots when larvae reached stage 4 . While the opened buds of the defoliated plants stopped growing as defoliation proceeded, the buds of non-irrigated saplings continued to grow but more slowly as the water content decreased in the pots. Expansive growth of leaves depends heavily on water availability (Tardieu et al. 2011; Tardieu et al. 2014). In the non-irrigated saplings, apical shoot and lateral twig growth were reduced by about $30 \%$ and $20 \%$, respectively, relative to the undefoliated saplings. As the physiological water deficit began when half of the primary growth was already completed, twig growth was less affected by the water deficit.

Radial growth at the base of the stem was reduced more by water deficit than by defoliation. Cambium division in the stem and tracheid enlargement stop earlier than usual during a period of water stress (Balducci et al. 2013; Steppe et al. 2015; Zweifel et al. 2006). According to Deslauriers et al. (2016), the number of xylem cells produced by the cambium is explained more strongly by water availability than by carbon supply. Under water deficit conditions, a sink growth limitation rules over source (C) limitation (Muller et al. 2011). This could explain why no additive or synergistic effects were found in the radial growth when the stresses were combined.

At the intra-annual level, however, we observed a divergent pattern in the defoliated-non-irrigated saplings. This suggests a positive effect of defoliation on the stem water reservoir. As the soil dries due to low water availability, transpiration causes stem dehydration. As a consequence, the stem water reservoir is progressively depleted (Bréda et al. 2006; Salomón et al. 2017), such as illustrated by the pronounced reversible stem shrinking observed in our non-irrigated trees. The use of water stored within stem tissues that are closer to the sites of evaporation may buffer temporary imbalances in the soil (Goldstein et al. 1998). In the non-irrigated-defoliated saplings, surprisingly, we did not observe any reversible stem shrinking. Therefore, the amount of water withdrawn from stem storage, substantially contributing to the total daily water loss for transpiration, was refilled on a daily basis (Steppe et al. 2015), avoiding strong stem contraction under drought conditions (Giovannelli et al. 2007; Salomón et al. 2017).

\subsection{Sapling mortality}

In agreement with our third hypothesis, the mortality rate in the post-stress period was caused primarily by a water deficit, although only during the first 2 weeks. Afterward, the mortality rate was constant and ranged between 0.05 and 0.1 dead saplings:day ${ }^{-1}$. It is widely reported that drought is responsible for tree mortality (Allen et al. 2010; Park Williams et al. 2013). The temporal scale of drought-induced tree mortality strongly depends on the physiological mechanisms that act as thresholds. In the black spruce stem, we determined the xylem tension that induces 50\% loss of conductivity (P50): $4.26 \mathrm{MPa}$ and the xylem air entry pressure $(P 12)$ of 2.9 MPa (Balducci et al. 2015).

In non-irrigated defoliated trees, however, the mortality rate was very low for 14 days following the water stress period. Moreover, none of the non-irrigated, defoliated saplings died during the first week following the resumption of irrigation. Since no stem dehydration was observed under waterstress conditions (see previous section), we propose that drought mortality in defoliated saplings could be temporarily reduced because of more readily available internal water when transpiration resumes after the water deficit. In other words, reduced foliar biomass would consequently decrease the transpiration flux, and as such, the stem water reservoir and root 
absorption would be more similar to water demand during the drought event.

\section{Conclusion}

The defoliation and water deficit effects (alone or in combination) were highly time dependent. Our results on sapling water status and growth point to two key periods during which defoliation negatively (1) or positively (2) affects plant water relations. First (1), a more negative water balance, observed during active defoliation, could favor branches (Deslauriers et al. 2015; Salmon et al. 2015) or even tree mortality, independent of drought. We observed a large difference in twig water potential between the undefoliated (optimal) and defoliated trees (suboptimal), which reflects a negative effect of defoliation. Under a combined stress, however, the effects of water stress prevail over defoliation-related stress. Second (2), it is only after the developing instars had begun to transform into moths that the detrimental effects of defoliation became positive for tree water balance (above optimal). Then, for the remainder of the study period, the water potential of defoliated saplings became less negative - including at the peak of drought - indicating a reduced transpiration demand and therefore a reduced post-drought mortality.

Acknowledgments We thank S. Rivest for his help in collecting the data.

Funding This study was funded by the "Programme de soutien à la recherche, volet Soutien à des initiatives internationales de recherche et d'innovation (PSR-SIIRI)," the Ministère du Développement économique, Innovation et Exportation du Québec (MDEIE), and the Natural Sciences and Engineering Research Council of Canada (Discovery Grant of A. Deslauriers).

Data availability Data are available upon request to the corresponding authors.

\section{Compliance with ethical standards}

Conflict of interest The authors declare that they have no conflicts of interest.

Publisher's note Springer Nature remains neutral with regard to jurisdictional claims in published maps and institutional affiliations.

\section{References}

Allen CD, Macalady AK, Chenchouni H, Bachelet D, McDowell N, Vennetier M, Kitzberger T, Rigling A, Breshears DD, Hogg EHT, Gonzalez P, Fensham R, Zhang Z, Castro J, Demidova N, Lim J-H, Allard G, Running SW, Semerci A, Cobb N (2010) A global overview of drought and heat-induced tree mortality reveals emerging climate change risks for forests. For Ecol Manag 259:660-684. https://doi.org/10.1016/j.foreco.2009.09.001
Balducci L, Deslauriers A, Giovannelli A, Rossi S, Rathgeber CBK (2013) Effects of temperature and water deficit on cambial activity and woody ring features in Picea mariana saplings. Tree Physiol 33: 1006-1017. https://doi.org/10.1093/treephys/tpt073

Balducci L, Deslauriers A, Giovannelli A, Beaulieu M, Delzon S, Rossi S, Rathgeber CBK (2015) How do drought and warming influence survival and wood traits of Picea mariana saplings? J Exp Bot 66: 377-389. https://doi.org/10.1093/jxb/eru431

Bansal S, Hallsby G, Löfvenius MO, Nilsson M-C (2013) Synergistic, additive and antagonistic impacts of drought and herbivory on Pinus sylvestris: leaf, tissue and whole-plant responses and recovery. Tree Physiol 33:451-463. https://doi.org/10.1093/treephys/tpt019

Bergeron Y, Leduc A, Joyal C, Morin H (1995) Balsam fir mortality following the last spruce budworm outbreak in northwestern Quebec. Can J For Res 25:1375-1384. https://doi.org/10.1139/ x95-150

Bernier PY (1993) Comparing natural and planted black spruce seedlings. I. Water relations and growth. Can J For Res 23:2427-2434. https:// doi.org/10.1139/x93-300

Bond BJ, Kavanagh KL (1999) Stomatal behavior of four woody species in relation to leaf-specific hydraulic conductance and threshold water potential. Tree Physiol 19:503-510. https://doi.org/10.1093/ treephys/19.8.503

Bouchard M, Kneeshaw D, Bergeron Y (2005) Mortality and stand renewal patterns following the last spruce budworm outbreak in mixed forests of western Quebec. For Ecol Manag 204:297-313. https:// doi.org/10.1016/j.foreco.2004.09.017

Bréda N, Huc R, Granier A, Dreyer E (2006) Temperate forest trees and stands under severe drought: a review of ecophysiological responses, adaptation processes and long-term consequences. Ann For Sci 63:625-644. https://doi.org/10.1051/forest:2006042

Brodribb TJ, Cochard H (2009) Hydraulic failure defines the recovery and point of death in water-stressed conifers. Plant Physiol 149:575584. https://doi.org/10.1104/pp.108.129783

Chen L, Huang J-G, Alam SA, Zhai L, Dawson A, Stadt KJ, Comeau PG (2017a) Drought causes reduced growth of trembling aspen in western Canada. Glob Chang Biol 23:2887-2902. https://doi.org/10. $1111 /$ gcb. 13595

Chen L, Huang JG, Dawson A, Zhai L, Stadt KJ, Comeau PG, Whitehouse C (2017b) Contributions of insects and droughts to growth decline of trembling aspen mixed boreal forest of western Canada. Glob Chang Biol 24:655-667. https://doi.org/10.1111/gcb. 13855

Choat B, Brodribb TJ, Brodersen CR, Duursma RA, López R, Medlyn BE (2018) Triggers of tree mortality under drought. Nature 558: 531-539. https://doi.org/10.1038/s41586-018-0240-x

Cochard H, Coll L, Le Roux X, Améglio T (2002) Unraveling the effects of plant hydraulics on stomatal closure during water stress in walnut. Plant Physiol 128:282-290. https://doi.org/10.1104/pp.010400

De Grandpré L, Kneeshaw DD, Perigon S, Boucher D, Marchand M, Pureswaran D, Girardin MP (2019) Adverse climatic periods precede and amplify defoliator-induced tree mortality in eastern boreal North America. J Ecol 107:452-467. https://doi.org/10.1111/13652745.13012

Delzon S, Cochard H (2014) Recent advances in tree hydraulics highlight the ecological significance of the hydraulic safety margin. New Phytol 203:355-358. https://doi.org/10.1111/nph.12798

Deslauriers A, Morin H, Bégin Y (2003) Cellular phenology of annual ring formation of Abies balsamea in Quebec boreal forest (Canada). Can J For Res 33:190-200. https://doi.org/10.1139/X02-178

Deslauriers A, Rossi S, Anfodillo T (2007) Dendrometer and intra-annual tree growth: what kind of information can be inferred? Dendrochronologia 25:113-124. https://doi.org/10.1016/j.dendro. 2007.05.003 
Deslauriers A, Caron L, Rossi S (2015) Carbon allocation during defoliation: testing a defense-growth trade-off in balsam fir. Front Plant Sci 6:1-13. https://doi.org/10.3389/fpls.2015.00338

Deslauriers A, Huang J, Balducci L, Beaulieu M, Rossi S (2016) The contribution of carbon and water in modulating wood formation in black spruce saplings. Plant Physiol 170:2072-2084. https://doi.org/ 10.1104/pp.15.01525

Deslauriers A, Fournier M-P, Cartenì F, Mackay J (2019) Spruce budworm defoliation leads to altered carbon allocation and earlier budburst in conifers. Tree Physiol, tpy135. https://doi.org/10.1093/ treephys/tpy 135

Dhont C, Sylvestre P, Gros-Louis M-C, Isabel N (2010) Field guide for identifying apical bud break and bud formation stages in white spruce. Natural Resources Canada, Québec

Eyles A, Pinkard EA, Mohammed C (2009) Shifts in biomass and resource allocation patterns following defoliation in Eucalyptus globulus growing with varying water and nutrient supplies. Tree Physiol 29:753-764. https://doi.org/10.1093/treephys/tpp014

Eyles A, Pinkard EA, Davies NW, Corkrey R, Churchill K, O'Grady AP, Sands P, Mohammed C (2013) Whole-plant versus leaf-level regulation of photosynthetic responses after partial defoliation in saplings. J Exp Bot 64:1625-1636. https://doi.org/10.1093/jxb/ert017

Fernández-de-Uña L, Rossi S, Aranda I, Fonti P, González-González BD, Cañellas I, Gea-Izquierdo G (2017) Xylem and leaf functional adjustments to drought in Pinus sylvestris and Quercus pyrenaica at their elevational boundary. Front Plant Sci 8:1-12. https://doi.org/ 10.3389/fpls.2017.01200

Forner A, Valladares F, Bonal D, Granier A, Grossiord C, Aranda I (2018) Extreme droughts affecting Mediterranean tree species' growth and water-use efficiency: the importance of timing. Tree Physiol 38: 1127-1137. https://doi.org/10.1093/treephys/tpy022

Giovannelli A, Deslauriers A, Fragnelli G, Scaletti L, Castro G, Rossi S, Crivellaro A (2007) Evaluation of drought response of two poplar clones (Populus $\times$ canadensis Mönch 'I-214' and P. deltoides Marsh. 'Dvina') through high resolution analysis of stem growth. J Exp Bot 58:2673-2683. https://doi.org/10.1093/jxb/erm117

Goldstein G, Andrade JL, Meinzer FC, Holbrook NM, Cavelier J, Jackson P, Celis A (1998) Stem water storage and diurnal patterns of water use in tropical forest canopy trees. Plant Cell Environ 21: 397-406. https://doi.org/10.1046/j.1365-3040.1998.00273.x

Grossnickle SC, Blake TJ (1987) Water relation patterns of bare-root and container jack pine and black spruce seedlings planted on boreal cutover sites. New For 1:101-116. https://doi.org/10.1007/bf00030055

Gruber A, Strobl S, Veit B, Oberhuber W (2010) Impact of drought on the temporal dynamics of wood formation in Pinus sylvestris. Tree Physiol 30:490-501. https://doi.org/10.1093/treephys/tpq003

Hennigar CR, MacLean DA, Quiring DT, Kershaw JA (2008) Differences in spruce budworm defoliation among balsam fir and white, red, and black spruce. For Sci 54:158-166. https://doi.org/10. 1139/X10-104

Jacquet J-S, Bosc A, O'Grady A, Jactel H (2014) Combined effects of defoliation and water stress on pine growth and non-structural carbohydrates. Tree Physiol 34:367-376. https://doi.org/10.1093/ treephys/tpu018

Maclean DA, Lidstone RG (1982) Defoliation by spruce budworm: estimation by ocular and shoot-count methods and variability among branches, trees, and stands. Can J For Res 12:582-594. https://doi. org $/ 10.1139 / \mathrm{x} 82-090$

Mencuccini M (2003) The ecological significance of long-distance water transport: short-term regulation, long-term acclimation and the hydraulic costs of stature across plant life forms. Plant Cell Environ 26: 163-182. https://doi.org/10.1046/j.1365-3040.2003.00991.x

Mitchell PJ, Battaglia M, Pinkard EA (2013) Counting the costs of multiple stressors: is the whole greater than the sum of the parts? Tree Physiol 33:447-450. https://doi.org/10.1093/treephys/tpt031
Morin H, Laprise D, Bergeron Y (1993) Chronology of spruce budwom outbreaks near Lake Duparquet, Abitibi region, Québec. Can J For Res 23:1497-1506. https://doi.org/10.1139/x93-189

Muller B, Pantin F, Genard M, Turc O, Freixes S, Piques M, Gibon Y (2011) Water deficits uncouple growth from photosynthesis, increase $\mathrm{C}$ content, and modify the relationships between $\mathrm{C}$ and growth in sink organs. J Exp Bot 62:1715-1729. https://doi.org/ $10.1093 / \mathrm{jxb} / \mathrm{erq} 438$

Niinemets Ü (2010) Responses of forest trees to single and multiple environmental stresses from seedlings to mature plants: past stress history, stress interactions, tolerance and acclimation. For Ecol Manag 260:1623-1639. https://doi.org/10.1016/j.foreco.2010.07. 054

Oberhuber W, Swidrak I, Pirkebner D, Gruber A (2011) Temporal dynamics of nonstructural carbohydrates and xylem growth in Pinus sylvestris exposed to drought. Can J For Res 41:1590-1597. https:// doi.org/10.1139/x11-084

Páez A, González OME, Yrausquín X, Salazar A, Casanova A (1995) Water stress and clipping management effects on Guineagrass: I. Growth and biomass allocation. Agron J 87:698-706. https://doi. org/10.2134/agronj1995.00021962008700040016x

Park Williams A, Allen CD, Macalady AK, Griffin D, Woodhouse CA, Meko DM, Swetnam TW, Rauscher SA, Seager R, Grissino-Mayer HD, Dean JS, Cook ER, Gangodagamage C, Cai M, McDowell N (2013) Temperature as a potent driver of regional forest drought stress and tree mortality. Nat Clim Chang 3:292-297. https://doi. org/10.1038/NCLIMATE1693

Peng C, Ma Z, Lei X, Zhu Q, Chen H, Wang W, Liu S, Li W, Fang X, Zhou X (2011) A drought-induced pervasive increase in tree mortality across Canada's boreal forests. Nat Clim Chang 1:467-471. https://doi.org/10.1038/NCLIMATE1293

Piene H, Maclean DA, Wall RE (1981) Effects of spruce budwormcaused defoliation on the growth of balsam fir: experimental design and methodology. Environment Canada, Canadian Forestry Service, Maritimes Forest Research Centre, Fredericton

Pureswaran DS, De Grandpré L, Paré D, Taylor A, Barrette M, Morin H, Régnière J, Kneeshaw DD (2015) Climate-induced changes in host tree-insect phenology may drive ecological state-shift in boreal forests. Ecology 96:1480-1491. https://doi.org/10.1890/13-2366.1

Quentin AG, O'Grady AP, Beadle CL, Worledge D, Pinkard EA (2011) Responses of transpiration and canopy conductance to partial defoliation of Eucalyptus globulus trees. Agric For Meteorol 151:356364. https://doi.org/10.1016/j.agrformet.2010.11.008

Quentin AG, O'Grady AP, Beadle CL, Mohammed C, Pinkard EA (2012) Interactive effects of water supply and defoliation on photosynthesis, plant water status and growth of Eucalyptus globulus Labill. Tree Physiol 32:958-967. https://doi.org/10.1093/treephys/ tps066

Roe AD, Demidovich M, Dedes J (2018) Origins and history of laboratory insect stocks in a multispecies insect production facility, with the proposal of standardized nomenclature and designation of formal standard names. J Insect Sci 18:1-9. https://doi.org/10.1093/jisesa/ iey037

Rossi S, Isabel N (2017) Bud break responds more strongly to daytime than night-time temperature under asymmetric experimental warming. Glob Chang Biol 23:446-454. https://doi.org/10.1111/ gcb. 13360

Rossi S, Morin H (2011) Demography and spatial dynamics in balsam fir stands after a spruce budworm outbreak. Can J For Res 41:11121120. https://doi.org/10.1139/x11-037

Rossi S, Deslauriers A, Morin H (2003) Application of the Gompertz equation for the study of xylem cell development. Dendrochronologia 21:33-39. https://doi.org/10.1078/1125-786500034

Rossi S, Simard S, Rathgeber CBK, Deslauriers A, De Zan C (2009) Effects of a 20-day-long dry period on cambial and apical meristem 
growth in Abies balsamea seedlings. Trees 23:85-93. https://doi. org/10.1007/s00468-008-0257-0

Salleo S, Nardini A, Raimondo F, Lo Gullo MA, Pace F, Giacomich P (2003) Effects of defoliation caused by the leaf miner Cameraria ohridella on wood production and efficiency in Aesculus hippocastanum growing in north-eastern Italy. Trees 17:367-375. https://doi.org/10.1007/s00468-003-0247-1

Salmon Y, Torres-Ruiz JM, Poyatos R, Martinez-Vilalta J, Meir P, Cochard H, Mencuccini M (2015) Balancing the risks of hydraulic failure and carbon starvation: a twig scale analysis in declining Scots pine. Plant Cell Environ 38:2575-2588. https://doi.org/10.1111/pce. 12572

Salomón RL, Limousin J-M, Ourcival J-M, Rodríguez-Calcerrada J, Steppe K (2017) Stem hydraulic capacitance decreases with drought stress: implications for modelling tree hydraulics in the Mediterranean oak Quercus ilex. Plant Cell Environ 40:13791391. https://doi.org/10.1111/pce.12928

Scherrer B (2007) Biostatistique, 2e edn. Gaetan Morin, Montréal

Schmid S, Palacio S, Hoch G (2017) Growth reduction after defoliation is independent of $\mathrm{CO}_{2}$ supply in deciduous and evergreen young oaks. New Phytol 214:1479-1490. https://doi.org/10.1111/nph.14484

Simard S, Morin H, Krause C, Buhay WM, Treydte K (2012) Tree-ring widths and isotopes of artificially defoliated balsam firs: a simulation of spruce budworm outbreaks in Eastern Canada. Environ Exp Bol 81:44-54. https://doi.org/10.1016/j.envexpbot.2012.02.012

Steppe K, Sterck F, Deslauriers A (2015) Diel growth dynamics in tree stems: linking anatomy and ecophysiology. Trends Plant Sci 20: 335-343. https://doi.org/10.1016/j.tplants.2015.03.015

Stewart JD, Bernier PY (1995) Gas exchange and water relations of 3 sizes of containerized Picea mariana seedlings subjected to atmospheric and edaphic water stress under controlled conditions. Ann For Sci 52:1-9. https://doi.org/10.1051/forest:19950101

Stewart JD, Zine El Abidine A, Bernier PY (1995) Stomatal and mesophyll limitations of photosynthesis in black spruce seedlings during multiple cycles of drought. Tree Physiol 15:57-64. https://doi.org/ 10.1093/treephys/15.1.57

Tan W, Blake TJ (1997) Gas exchange and water relations responses to drought of fast- and slow-growing black spruce families. Can J Bot 75:1700-1706. https://doi.org/10.1139/b97-884
Tardieu F, Granier C, Muller B (2011) Water deficit and growth. Coordinating processes without an orchestrator? Curr Opin Plant Biol 14:283-289. https://doi.org/10.1016/j.pbi.2011.02.002

Tardieu F, Parent B, Caldeira CF, Welcker C (2014) Genetic and physiological controls of growth under water deficit. Plant Physiol 164: 1628-1635. https://doi.org/10.1104/pp.113.233353

Topp GC, Zebchuk WD, Davis JL, Bailey WG (1984) The measurement of soil water content using a portable TDR hand probe. Can J Soil Sci 64:313-321. https://doi.org/10.4141/cjss84-033

Tyree MT (2003) Hydraulic limits on tree performance: transpiration, carbon gain and growth of trees. Trees 17:95-100. https://doi.org/ 10.1007/s00468-002-0227-x

Tyree MT, Zimmermann MH (2002) Xylem structure and the ascent of sap. Springer, Berlin

Vanderklein DW, Reich PB (2000) European larch and eastern white pine respond similarly during three years of partial defoliation. Tree Physiol 20:283-287. https://doi.org/10.1093/treephys/20.4.283

Wiley E, Huepenbecker S, Casper BB, Helliker BR (2013) The effects of defoliation on carbon allocation: can carbon limitation reduce growth in favour of storage? Tree Physiol 33:1216-1228. https:// doi.org/10.1093/treephys/tpt093

Zhai L, Bergeron Y, Huang JG, Berninger F (2012) Variation in intraannual wood formation, and foliage and shoot development of three major Canadian boreal tree species. Am J Bot 99:827-837. https:// doi.org/10.3732/ajb.1100235

Zhang X, Lei Y, Ma Z, Kneeshaw D, Peng CH (2014) Insect-induced tree mortality of boreal forest in eastern Canada under a changing climate. Ecol Evol 4:2384-2394. https://doi.org/10.3389/fpls.2015. 00338

Zine El Abidine A, Bernier PY, Stewart JD, Plamondon AP (1994) Water stress preconditioning of black spruce seedlings from lowland and upland sites. Can J Bot 72:1511-1518. https://doi.org/10.1139/b94186

Zweifel R, Zimmermann L, Zeugin F, Newbery D (2006) Intra-annual radial growth and water relations of trees: implications towards a growth mechanism. J Exp Bot 57:1445-1459. https://doi.org/10. 1093/jxb/erj125 